\title{
Effect of Glucocorticoid on Piglet Jejunal Mucosa during Acute Viral Enteritis ${ }^{1}$
}

\author{
J. MARC RHOADS, R. JOHN MACLEOD, AND J. RICHARD HAMILTON \\ Research Institute, The Hospital for Sick Children and Division of Gastroenterology, Department of Pediatrics, \\ University of Toronto, Ontario, Canada
}

\begin{abstract}
We measured the effect of pharmacological doses of glucocorticoid on piglet jejunal structure and function during acute viral diarrhea. Weaned piglets, infected experimentally with transmissible gastroenteritis virus, a coronavirus that induces a diarrheal illness similar to human rotavirus infection, received methylprednisolone $(30 \mathrm{mg} / \mathrm{kg}$ ) or saline intramuscularly at 48 and $72 \mathrm{~h}$ after infection; noninfected littermate controls were similarly injected with methylprednisolone. Animals were killed at $96 \mathrm{~h}$, at the height of diarrhea, and jejunal epithelium was studied in vitro. Transmissible gastroenteritis, as expected, induced structural, enzyme, and $\mathrm{Na}$ transport abnormalities. Methylprednisolone did not affect small intestinal structure or function of noninfected control piglets. In transmissible gastroenteritis-infected piglets, jejunal villi were longer and glucose-facilitated $\mathrm{Na}$ absorption was greater after methylprednisolone than after saline treatment. Increased glucose stimulation of $\mathrm{Na}$ flux in vitro in the methylprednisolone-treated infected group was not attributable to enhanced $\mathrm{Na}^{+}-\mathrm{K}^{+}$-ATPase activity and occurred despite persistence of the virus within mucosal cells, shown by immunofluorescense microscopy. In this piglet model of viral diarrhea, early regeneration of absorptive surface that precedes recovery of disaccharidase function is accelerated by glucocorticoid therapy. (Pediatr Res 23: 279-282, 1988)
\end{abstract}

\section{Abbreviations}

Isc, short-circuit current

Na, sodium

MP, methylprednisolone

$\mathbf{J}_{\mathrm{ms}}^{\mathrm{Na}}, \mathrm{Na}$ flux from mucosa to serosa

$\mathbf{J}_{\mathrm{sm}}^{\mathrm{Na}}, \mathrm{Na}$ flux from serosa to mucosa

$\mathbf{J}_{\text {net }}^{\mathrm{Na}}$, Net Na flux

$\Delta \mathbf{J}_{\text {net, }}^{\mathrm{Na}}$ increment in net $\mathrm{Na}$ flux

$\mathrm{Na}^{+}-\mathrm{K}^{+}$-ATPase, sodium-potassium-stimulated adenosine triphosphatase

TGE, transmissible gastroenteritis

ANOVA, analysis of variance

$\mathrm{G}$, conductance

TGE is an invasive viral enteritis occurring in young pigs (1). The impact of this coronavirus infection on the small intestine

Received February 17, 1987; accepted November 4, 1987.

Requests for reprints J. Richard Hamilton, M.D., Department of Pediatrics, Montreal Children's Hospital, 2300 Tupper Street, Montreal, Quebec, Canada H3H 1 P3.

Supported by a grant from the Medical Research Council of Canada. J.M.R. was a recipient of a research fellowship from the Canadian Cystic Fibrosis Foundation.

' Presented at the annual meeting of the American Gastroenterology Association, San Francisco, CA, May 1986. resembles that of human rotavirus $(1,2)$. Watery diarrhea is attributable to a loss of functioning differentiated enterocytes and dominance of the epithelium by relatively undifferentiated cells (1-4).

Glucocorticoids in pharmacological doses may influence small intestinal epithelial differentiation. In suckling rabbits, glucocorticoid accelerates the appearance in the intestinal brush border of active disaccharidases and stimulates precocious development of glucose-facilitated $\mathrm{Na}$ transport (5). Furthermore, under some experimental conditions, pharmacological doses of glucocorticoid augment the activity of rat intestinal mucosal $\mathrm{Na}^{+}-\mathrm{K}^{+}-$ ATPase (5-7); in both rats and humans they enhance in vivo absorption of $\mathrm{Na}$, water, and glucose $(6 ; 8)$.

Therefore, we studied the effect of pharmacological doses of MP on the response of piglet small intestine to experimentally induced infection with TGE virus. These experiments focused on the jejunal epithelium, its structure, enzyme activities, and transport function.

\section{MATERIALS AND METHODS}

Thirteen York-Landrance piglets, 17-21 days old, were weaned and fed evaporated cow's milk for 3 days. Eight piglets received a standard intragastic inoculum of Purdue strain of TGE virus (1) and five uninfected littermates were used as controls. Three uninfected piglets received MP (30 mg/kg intramuscularly) on the 17th and 18th day of life (control MP). Of the eight TGE-infected pigs, four received MP $(30 \mathrm{mg} / \mathrm{kg}$ intramuscularly) 48 and $72 \mathrm{~h}$ after TGE inoculation (TGE-MP) and the other four were injected with an identical volume of saline (TGE-saline).

For intestinal studies, piglets were killed by a parenteral injection of $325 \mathrm{mg}$ pentobarbital sodium. Beginning $10 \mathrm{~cm}$ distal to the ligament of Treitz, the first $10-12 \mathrm{~cm}$ of jejunum were removed quickly, flushed with normal saline, stripped of muscle, and mounted in conventional Ussing chambers (exposing an area of $1.29 \mathrm{~cm}^{2}$ ) for studies of ion transport (4). The next 25 $\mathrm{cm}$ was removed, flushed with saline, and processed as follows: the first $1-\mathrm{cm}$ segment was quick-frozen for viral immunofluorescence; the next $\mathrm{cm}$ was fixed in Bouin's solution, blocked in paraffin, and stained with hematoxylin and eosin; and from the remaining $23 \mathrm{~cm}$, mucosa was scraped with a glass slide, homogenized with a Dounce homogenizer, and frozen at $-70^{\circ} \mathrm{C}$. This frozen homogenate was assayed for sucrase, lactase (9), $\mathrm{Na}^{+}-\mathrm{K}^{+}$ATPase (2), and thymidine kinase (4); results are expressed as specific activities.

For ion flux measurements, mucosal and serosal sides of the tissue were bathed at $37^{\circ} \mathrm{C}$ in $10 \mathrm{ml}$ oxygenated Krebs-Ringer bicarbonate buffer ( $\mathrm{pH}$ 7.4) containing (mM): $\mathrm{Na} 143$, potassium 10 , magnesium 1.11 , calcium 1.25 , chloride $128, \mathrm{HCO}_{3} 25$, $\mathrm{H}_{2} \mathrm{PO}_{4} 2$, and acetate 3 . Acetate was provided for tissue energy metabolism. In each experiment, jejunal tissue was mounted in the chambers within $30 \mathrm{~min}$ of the piglet's death and Isc was adjusted at 10 -min intervals (10). Transmucosal potential differ- 
ences and conductances were stable indicating tissue viability during each of these 2 -h studies. We added ${ }^{22} \mathrm{Na}$ to mucosal or serosal chambers initially and, after a 15-min equilibration period, withdrew 1-ml samples from each chamber at 10-min intervals. We calculated undirectional $\mathrm{Na}$ fluxes from the rate of appearance of label in the opposite chamber. After $55 \mathrm{~min}$, we added $5 \mathrm{ml}$ of Krebs buffer containing D-glucose (30 mM final concentration) to the mucosal and serosal chambers, and again measured unidirectional $\mathrm{Na}$ fluxes, sampling from the chambers at 10 -min intervals for $1 \mathrm{~h}$. We calculated $J_{\mathrm{ms}}^{\mathrm{Na}}$ and $J_{\mathrm{sm}}^{\mathrm{Na}}$ using jejunal segments paired so that $G$ did not differ by more than $25 \%$. Net Na flux was calculated by the formula $J_{n e t}^{\mathrm{Na}}=J_{\mathrm{ms}}^{\mathrm{Na}}-J_{\mathrm{sm}}^{\mathrm{Na}}$.

Preliminary studies of TGE viral antigen in the mucosa used direct immunofluorescence with fluorescein-conjugated porcine anti-TGE globulin, as previously described (3). Jejunal sections were interpreted, without prior identification, by an observer who routinely performs TGE immunofluorescence. Results were reported as positive (diffuse fluorescence of enterocytes), weakly positive (weak fluorescence of occasional enterocytes), or negative (3). For light microscopic studies, all specimens were examined by the same observer without prior identification, using a calibrated micrometer eye piece to measure $10-15$ representative crypt villus units.

${ }^{22} \mathrm{Na}$ was obtained from Amersham (Montreal, Canada), Dglucose from BDH Chemicals (Toronto, Ontario, Canada). The remaining reagents were obtained from Sigma Chemical (St. Louis, MO).

Mucosal structure and enzymes were compared in the four groups of piglets using one-way ANOVA. For data involving comparisons of means between several groups, we used Scheffe's multiple comparisons method (11). For transport studies, $\mathrm{Na}$ fluxes under basal conditions were compared with those after adding D-glucose using the $t$ test for paired variates. Based on the hypothesis that MP would increase transport (5-8), we compared jejunal Na transport in MP-treated pigs (uninfected, TGE-

Table 1. Piglet jejunum-light microscopic measurements (mean $\pm S E M)$

\begin{tabular}{lcccc}
\hline & $\begin{array}{c}\text { Control } \\
(n=2)\end{array}$ & $\begin{array}{c}\text { Uninfected-MP } \\
(n=3)\end{array}$ & $\begin{array}{c}\text { TGE-saline } \\
(n=4)\end{array}$ & $\begin{array}{c}\text { TGE-MP } \\
(n=4)\end{array}$ \\
\hline Villus ht $(\mu \mathrm{m})$ & $294 \pm 8$ & $313 \pm 32$ & $86 \pm 16^{*}$ & $190 \pm 12^{*} \dagger$ \\
Crypt depth $(\mu \mathrm{m})$ & $122 \pm 2$ & $124 \pm 7$ & $231 \pm 33$ & $226 \pm 29$ \\
\hline
\end{tabular}

${ }^{*} p<0.05$ compared with controls.

$\dagger p<0.05$ compared with TGE infected, saline injected. infected) with $\mathrm{Na}$ transport in their corresponding controls using Student's one-tailed $t$ test.

\section{RESULTS}

Clinical findings. No changes in behavior or stooling pattern were noted in uninfected piglets treated with MP. Infected piglets all developed anorexia and appeared ill. Each of the four infected pigs given saline developed diarrhea and demonstrated a fluidfilled small bowel at $96 \mathrm{~h}$. Of the four infected animals injected with MP, three developed diarrhea but only one showed a fluidfilled intestine at $96 \mathrm{~h}$. The four MP-treated infected piglets weighed approximately the same $(2390 \pm 150 \mathrm{~g})$ as their salineinjected counterparts $(2530 \pm 160 \mathrm{~g})$. Also, the weights of the proximal and distal small bowel after flushing with saline did not differ in the two groups.

Microscopic studies (Table 1). MP treatment did not alter jejunal structure of uninfected piglets compared with controls. Ninety-six $h$ after TGE infection jejunal villi were blunted $(p<$ $0.05)$ regardless of whether animals had received saline or MP. However, in comparing the two TGE-infected groups, we observed taller villi $(p<0.05)$ and, in most preparations, less inflammation of the lamina propria in MP-treated animals than in saline-treated controls.

In 96-h TGE jejunum, TGE immunofluorescence was only weakly positive in two and negative in the other two preparations from saline-treated piglets. In MP-treated TGE-jejunum at $96 \mathrm{~h}$, three preparations were available for immunofluorescence staining, and, in all of these, immunofluorescence was strongly positive. These preliminary observations suggested MP had delayed viral clearance.

Jejunal mucosal enzymes (Table 2). In uninfected pigs, activities of disaccharidases, $\mathrm{Na}^{+}-\mathrm{K}^{+}$-ATPase, and thymidine kinase were not altered by MP injection. Reductions of sucrase and $\mathrm{Na}^{+}-\mathrm{K}^{+}$-ATPase activities were observed in the jejuna of both groups of 96-h TGE-injected piglets (saline-injected and MPinjected) ( $p<0.05$, compared with uninjected controls). While mean thymidine kinase activity tended to be higher and lactase tended to be lower in TGE jejunum than in controls, the results were not statistically significant.

MP had no significant effect on sucrase, lactase, $\mathrm{Na}^{+}-\mathrm{K}^{+}$ATPase, or thymidine kinase activities in TGE-infected pigs, regardless of whether activities were related to mucosal protein, intestinal wet weight, or length.

Table 2. Piglet jejunum-enzyme-specific activities in whole mucosal homogenates (mean \pm SEM)

\begin{tabular}{|c|c|c|c|c|}
\hline & $\begin{array}{l}\text { Control } \\
(n=2)\end{array}$ & $\begin{array}{l}\text { Uninfected-MP } \\
\quad(n=3)\end{array}$ & $\begin{array}{l}\text { TGE-Saline } \\
(n=4)\end{array}$ & $\begin{array}{c}\text { TGE-MP } \\
(n=4)\end{array}$ \\
\hline Sucrase $\left(\mu \mathrm{mol} \cdot \mathrm{g}^{-1} \cdot \mathrm{min}^{-1}\right)$ & $45.7 \pm 4.8$ & $48.5 \pm 12.7$ & $2.5 \pm 0.1^{*}$ & $3.1 \pm 0.5^{*}$ \\
\hline Lactase $\left(\mu \mathrm{mol} \cdot \mathrm{g}^{-1} \cdot \mathrm{min}^{-1}\right)$ & $56.8 \pm 10.9$ & $64.3 \pm 22.9$ & $4.4 \pm 1.8$ & $5.9 \pm 0.8$ \\
\hline $\mathrm{Na}^{+}-\mathrm{K}^{+}$-ATPase $\left(\mathrm{pmol} \mathrm{P}_{\mathrm{i}} \cdot \mathrm{mg}^{-1} \mathrm{~min}^{-1}\right)$ & $92.5 \pm 7.5$ & $98.3 \pm 9.7$ & $52.1 \pm 2.6^{*}$ & $52.7 \pm 4.3^{*}$ \\
\hline Thymidine kinase $\left(\mathrm{pmol} \cdot \mathrm{mg}^{-1} \cdot \mathrm{h}^{-1}\right)$ & $10.2 \pm 3.0$ & $9.4 \pm 1.6$ & $97.2 \pm 42.7$ & $100.5 \pm 46.2$ \\
\hline
\end{tabular}

${ }^{*} p<0.05$ compared with controls or uninfected MP.

Table 3. Piglet jejunum: transmucosal unidirectional and net Na fluxes $\left(\mu E q \cdot \mathrm{cm}^{-2} \cdot \mathrm{h}^{-1}\right), I s c\left(\mu E q . \mathrm{cm}^{-2} \cdot \mathrm{h}^{-1}\right)$, and $G\left(\mathrm{mmho} \cdot \mathrm{cm}^{-2}\right)$; uninfected pigs (saline vs. MP injected) (mean $\pm S E M$ )

\begin{tabular}{|c|c|c|c|c|c|c|c|}
\hline & $n$ & $\begin{array}{c}\mathrm{Na} \\
\mathrm{Jms}\end{array}$ & $\begin{array}{c}\mathrm{Na} \\
\mathrm{Jsm}\end{array}$ & $\begin{array}{c}\mathrm{Na} \\
\text { Jnet }\end{array}$ & $\begin{array}{c}\mathrm{Na} \\
\Delta \mathrm{Jnet}\end{array}$ & Isc & G \\
\hline \multicolumn{8}{|l|}{ Basal } \\
\hline Control & 6 & $11.3 \pm 1.0$ & $12.7 \pm 0.8$ & $-1.4 \pm 0.4$ & & $2.8 \pm 0.3$ & $26.8 \pm 1.5$ \\
\hline Uninfected-MP & 6 & $10.5 \pm 0.4$ & $12.8 \pm 0.5$ & $-2.3 \pm 0.9$ & & $2.9 \pm 1.5$ & $26.6 \pm 1.5$ \\
\hline \multicolumn{8}{|l|}{ D-glucose $(30 \mathrm{mM})$} \\
\hline Control & 6 & $14.1 \pm 1.1$ & $11.3 \pm 0.7$ & $2.8 \pm 0.9^{*}$ & $4.2 \pm 1.0$ & $7.9 \pm 1.0^{*}$ & $29.9 \pm 0.7$ \\
\hline Uninfected-MP & 6 & $13.3 \pm 0.5$ & $11.7 \pm 0.6$ & $1.6 \pm 1.0^{*}$ & $3.9 \pm 0.7$ & $7.8 \pm 0.5^{*}$ & $29.3 \pm 0.9$ \\
\hline
\end{tabular}

${ }^{*} p<0.05$ compared with basal period. 
$\mathrm{Na}$ transport data. Measured in vitro in Ussing chambers, transmucosal unidirectional $\mathrm{Na}$ fluxes $\left(\mathrm{J}_{\mathrm{ms}}^{\mathrm{Na}}, J_{\mathrm{sm}}^{\mathrm{Na}}\right)$ and $\mathrm{G}$ in uninfected MP-treated pigs did not differ from those of controls (Table 3). After D-glucose ( $30 \mathrm{mM}), \mathrm{J}_{\text {net }}^{\mathrm{Na}}$ and Isc increased in both groups of uninfected piglets $(p<0.05)$, and there was no difference in the magnitude of these responses between MP-treated $\left(\Delta \mathrm{J}_{\mathrm{net}}^{\mathrm{Na}}=4.2 \pm 1.0 \mu \mathrm{Eq} \cdot \mathrm{cm}^{-2} \cdot \mathrm{h}^{-1}\right)$ and untreated control tissue $\left(\Delta \mathrm{J}_{\text {net }}^{\mathrm{Na}}=3.9 \pm 0.7 \mu \mathrm{Eq} \cdot \mathrm{cm}^{-2} \cdot \mathrm{h}^{-1}\right)$ (Fig. 1).

Ussing chamber transport data from 96-h TGE-infected piglets are shown in Table 4 and Figure 1, which compare jejunal $\mathrm{Na}$ transport response to D-glucose of MP-injected animals with that of saline-injected litter mates. Basal mucosal to serosal Na flux was modestly enhanced in MP-treated animals, but net $\mathrm{Na}$ flux was secretory and did not differ from controls. After $30 \mathrm{mM} \mathrm{D}-$ glucose, $\mathbf{J}_{\mathrm{net}}^{\mathrm{Na}}$ increased in both saline-injected and MP-treated TGE jejunum $(p<0.01)$; however, only in the glucocorticoidtreated group did net $\mathrm{Na}$ flux become absorptive $\left(\mathrm{J}_{\text {net }}^{\mathrm{Na}}=0.6 \pm\right.$ $0.5 \mu \mathrm{Eq} \cdot \mathrm{cm}^{-2} \cdot \mathrm{h}^{-1} ; \mathrm{p}<0.01$ compared with basal $\left.\mathbf{J}_{\text {net }}^{\mathrm{Na}}\right)$. The net response to D-glucose in MP-treated piglet jejunum $\left(\Delta \mathrm{J}_{\mathrm{net}}^{\mathrm{Na}}=1.6\right.$ $\left.\pm 0.4 \mu \mathrm{Eq} \cdot \mathrm{cm}^{-2} \cdot \mathrm{h}^{-1}\right)$ significantly exceeded response of salineinjected TGE-injected jejunum $\left(\Delta \mathrm{J}_{\mathrm{net}}^{\mathrm{Na}}=0.5 \pm 0.2 \mu \mathrm{Eq} \cdot \mathrm{cm}^{-2}\right.$. $\mathrm{h}^{-1}$ ) (Fig. 1). There were small increases in $J_{\mathrm{sm}}^{\mathrm{Na}}$ and $\mathrm{G}$ after $\mathrm{D}-$ glucose in both groups, which were significant only in salinetreated piglets; however, the magnitude of these changes $\left(\Delta \mathrm{J}_{\mathrm{sm}}^{\mathrm{Na}}\right.$, $\Delta G$ ) did not differ between the two groups.

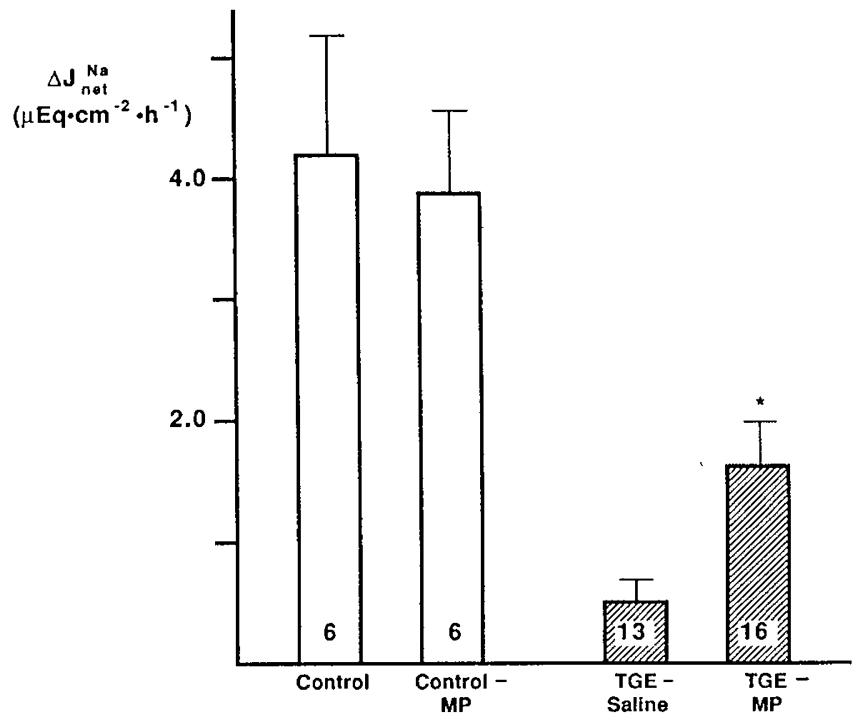

Fig. 1. Increase of net $\mathrm{Na}$ flux $\left(\Delta \mathrm{J}_{n e l}^{\mathrm{Na}}\right.$ ) in control (open bars) and TGE (shaded bars) piglet jejunum, measured in Ussing chambers, in response to $30 \mathrm{mM}$ D-glucose. Responses of control and TGE-infected jejuna are compared with normal and TGE-infected pigs injected with MP as described in "Materials and Methods." * $p<0.05$ compared with salineinjected TGE group.

\section{DISCUSSION}

Short-term, high-dose, glucocorticoid treatment of normal piglets did not alter jejunal structure, enzymes, or glucose-facilitated $\mathrm{Na}$ transport in the current experiments. Previous studies using similar doses in rats found increased ileal villus height (12), increased disaccharidase activities (12), and enhanced electroneutral $\mathrm{NaCl}$ transport (13) in response to corticosteroid. Furthermore, MP (20-30 mg/ kg) has been shown to stimulate basal ileal $\mathrm{Na}$ and $\mathrm{Cl}$ transport $(13,14)$ and ileal response to combined absorptive stimuli (glucose + alanine + epinephrine) (14) after only $24-48 \mathrm{~h}$ of treatment. Because we found MP treatment had no impact on basal jejunal Isc, we conclude that glucocorticoid treatment did not stimulate electrogenic chloride secretion, as reported in rat (15) and rabbit (16) ileum by others. These discrepancies between our data and those reported previously could be attributed to many possible factors, including species specificity, differences in the responses of jejunum and ileum, and the relatively brief period of MP treatment we used.

We gave MP at 48 and $72 \mathrm{~h}$ after TGE inoculation because previous studies showed maximal jejunal injury and viral shedding before $40 \mathrm{~h}$ after infection (3), when the epithelium is most undifferentiated and presumably most responsive to glucocorticoid $(17,18)$. As recovery from TGE-induced injury in untreated pigs is complete by $144 \mathrm{~h}(4)$ we studied jejunal tissue at $96 \mathrm{~h}$, expecting animals at this stage to show partial villus recovery but little or no virus remaining in the epithelium.

Glucocorticoid treatment clearly did not alter disaccharidase activity in either normal pigs or in those with viral diarrhea. In the normal group, the lack of effect of MP probably reflects a functionally mature mucosal disaccharidase pattern in the weaned animal. However, in the TGE-infected epithelium, low disaccharidase activities persisted after MP treatment, despite a lengthening of villi in MP-treated animals. Studies in suckling rats showed the effects of glucocorticoid require emergence of cells from the crypts, with maximal effects on mucosal sucrase after $120 \mathrm{~h}$ (19). Consequently, we expected an earlier response in TGE epithelia, because enterocyte transit time decreases from approximately 55 to $18 \mathrm{~h}$ in this disease (3). TGE jejunal cells, therefore, differ from those of the developing gut not only in their rapid proliferation but also in their failure to respond by 48 $h$ to adrenocorticoid by synthesis or activation of brush border digestive enzymes.

In the virus-damaged epithelium, glucocorticoid treatment did enhance functional maturity as reflected by jejunal villus structure and the Na-absorptive response to glucose. Accelerated enterocyte migration, observed after long-term corticosteroid treatment (12), could have contributed to this observation. In previous studies of suckling rabbits treated with cortisone (5) we attributed precocious development of jejunal glucose-facilitated $\mathrm{Na}$ transport to increased lumen to cell driving forces resulting from enhanced $\mathrm{Na}^{+}-\mathrm{K}^{+}$-ATPase activity. However, our current data demonstrate increased glucose-stimulated $\mathrm{Na}$ absorption in the weaned piglet in the absence of altered $\mathrm{Na}^{+}-\mathrm{K}^{+}$-ATPase

Table 4. Piglet jejunum: transmucosal unidirectional and net Na Fluxes $\left(\mu E q \cdot \mathrm{cm}^{-2} \cdot h^{-1}\right), I s c\left(\mu E q \cdot \mathrm{cm}^{-2} \cdot h^{-1}\right)$, and $G(m m h o$. $\mathrm{cm}^{-2}$ ); 96-h TGE-infected pigs (saline vs MP-injected) (mean $\pm S E M$ )

\begin{tabular}{|c|c|c|c|c|c|c|c|}
\hline & $n$ & $\begin{array}{l}\mathrm{Na} \\
\mathrm{Jms}\end{array}$ & $\begin{array}{c}\mathrm{Na} \\
\mathrm{Jsm}\end{array}$ & $\begin{array}{c}\mathrm{Na} \\
\text { Jnet }\end{array}$ & $\begin{array}{c}\mathrm{Na} \\
\Delta \mathrm{J} \text { net }\end{array}$ & Isc & $\mathrm{G}$ \\
\hline \multicolumn{8}{|l|}{ Basal } \\
\hline TGE-saline & 13 & $4.8 \pm 0.4$ & $6.4 \pm 0.3$ & $-1.6 \pm 0.3$ & & $1.5 \pm 0.1$ & $13.2 \pm 0.6$ \\
\hline TGE-MP & 16 & $6.0 \pm 0.6^{*}$ & $7.1 \pm 0.4$ & $-1.0 \pm 0.4$ & & $1.4 \pm 0.1$ & $14.8 \pm 1.0$ \\
\hline \multicolumn{8}{|c|}{ D-glucose $(30 \mathrm{mM})$} \\
\hline TGE-saline & 13 & $6.3 \pm 0.2 \dagger$ & $7.4 \pm 0.3 \dagger$ & $-1.1 \pm 0.2 \ddagger$ & $0.5 \pm 0.2$ & $3.0 \pm 0.3 \ddagger$ & $15.8 \pm 0.9 \ddagger$ \\
\hline TGE-MP & 16 & $8.2 \pm 0.6^{*} \dagger$ & $7.6 \pm 0.4$ & $0.6 \pm 0.5^{* \dagger}$ & $1.6 \pm 0.4^{*}$ & $3.6 \pm 0.3 \ddagger$ & $16.4 \pm 0.6$ \\
\hline
\end{tabular}

$* p<0.05$ compared with saline-injected group.

$\dagger p<0.01$ compared with basal Na flux.

$\ddagger p<0.05$ compared with basal $\mathrm{Na}$ flux. 
activity, suggesting that the glucocorticoid effect observed was independent of the activity of the basolateral membrane $\mathrm{Na}$ pump. Rapid activation of the $\mathrm{Na}^{+}-\mathrm{K}^{+}$pump can occur as a result of a sudden increase in intracellular $\mathrm{Na}(20)$. In rabbit descending colon glucocorticoid treatment was recently shown to enhance apical $\mathrm{Na}$ permeability (21), which in turn would rapidly activate $\mathrm{Na}^{+}-\mathrm{K}^{+}$-ATPase. Our data do not preclude MP effects on brush border permeability and/or basolateral pump function but they do indicate that MP does not alter $\mathrm{Na}^{+}-\mathrm{K}^{+}$ATPase specific activity in the jejunum and that it has no major effect on basal $\mathrm{Na}$ transport in control or TGE jejunum. The augmented jejunal response to D-glucose $\left(\Delta \mathrm{J}_{\text {net }}^{\mathrm{Na}}\right)$ we observed in the MP-treated infected piglet is compatible with the hypothesis that glucocorticoid alters brush border glucose-Na cotransport, as observed in intestinal brush border membrane vesicles from rats injected with triamcinolone (22). Alternatively, MP may alter jejunal glucose-Na cotransport simply by increasing absorptive surface area.

Increased glucose-stimulated $\mathrm{Na}$ absorption in the treated pigs was not due to enhanced elimination of virus from the epithelium. Our data showing villus blunting and a 10 -fold reduction in mucosal disaccharidases in MP-treated infected piglets suggest the drug did not interfere with exfoliation of infected villus cells. However, the finding of homogeneous immunofluorescence of enterocytes at $96 \mathrm{~h}$, in the MP-treated group only, suggests that glucocorticoid treatment may interfere with viral clearance from the mucosa. Determination of the effects of MP on viral clearance was not the aim of the present study and would require sequential quantitation of virus in the mucosa and intestinal fluid. Our finding, however, is compatible with the theory that MP treatment could facilitate persistence of virus beyond the 40h stage, when it is normally cleared (3).

Although the TGE model in the piglet represents a major human disease, human rotavirus enteritis, our data should not be interpreted to suggest that corticosteroid treatment of babies with severe viral enteritis would be beneficial. In fact, the observation that virus may be retained in the epithelium after MPtreatment suggests such treatment is contraindicated. Our findings do indicate that the relatively undifferentiated epithelium occurring in this acute viral enteritis is responsive to hormonal influences.

Acknowledgments. The authors are grateful to Krys Streich, Mahmood Khan, Helen Conway, and William Wilson for expert technical assistance, to Shelley Goodman and Martha Long for secretarial assistance; to Kathy Holland for assistance with the statistical analysis; and to Drs. Brian Darbyshire and Douglas Key, Department of Microbiology, Ontario Veterinary College, Guelph, Ontario for assistance in fluorescent antibody studies.

\section{REFERENCES}

1. Butler DG, Gall DG, Kelly MH, Hamilton JR 1974 Transmissible gastroenteritis. Mechanisms responsible for diarrhea in an acute viral enteritis in piglets. J Clin Invest 53:1335-1342

2. Kelly M, Butler DG, Hamilton JR 1972 Transmissible gastroenteritis of piglets: a model of infantile viral diarrhea. J Pediatr 80:925-931

3. Shepherd RW, Butler DG, Cutz E, Gall DG, Hamilton JR 1979 The mucosal lesion in viral enteritis: extent and dynamics of the epithelial response to virus invasion in transmissible gastroenteritis of piglets. Gastroenterology 76:770-777

4. Kerzner B, Kelly MH, Gall DG, Butler DG, Hamilton JR 1977 Transmissible gastroenteritis: sodium transport and the intestinal epithelium during the course of viral enteritis. Gastroenterology 72:457-461

5. Guiraldes E, Gall DG, Hamilton JR 1981 Effect of cortisone on postnatal development of ion transport in rabbit small intestine. Pediatr Res 15:15301532

6. Charney AN, Kinsey MD, Myers L, Gianella RA, Gots RE $1975 \mathrm{Na}^{+}-\mathrm{K}^{+}-$ activated adenosine triphosphatase and intestinal electrolyte transport. Effect of adrenal steroids. J Clin Invest 56:653-660

7. Binder HJ 1978 Effect of dexamethasone on electrolyte transport in the large intestine of the rat. Gastroenterology 75:212-217

8. Crake T, Crisp AJ, Shearing M, Record CO, Sandle GI 1984 Effect of intraluminal hydrocortisone on solute and water absorption in the human jejunum. Clin Science 67:105-110

9. Dahlquist A 1964 Method for assay of intestinal disaccharidases. Anal Biochem 7:18-25

10. Schultz SG, Zalusky R 1964 Ion transport in isolated rabbit ileum. I. Shortcircuit current and Na fluxes. J Gen Physiol 47:567-584

11. Godfiey K 1985 Statistics in practice. Comparing the mean of several groups. N Engl J Med 313:1450-1456

12. Batt RM, Peters TJ 1976 Effects of prednisolone on the small intestinal mucosa of the rat. Clin Sci Mol Med 50:511-523

13. Harris MS, Tan E 1985 Stimulation of neutral $\mathrm{NaCl}$ absorption by glucocorticoids and $\mathrm{Na}$ depletion in rat ileum in vivo. Gastroenterology 88:1413 (abstr)

14. Sellin JH, DeSoignie R 1983 Methylprednisolone increases absorptive capacity of rabbit ileum in vitro. Am J Physiol G562-G567

15. Tai YH, Decker RA, Marnane WG, Charney AN, Donowitz M 1981 Effects of methylprednisolone on electrolyte transport by in vitro rat ileum. Am J Physiol 240:G365-G370

16. Sellin JH, Field M 1981 Physiologic and pharmacologic effects of glucocorticoids on ion transport across rabbit ileal mucosa in vitro. J Clin Invest 67:770-778

17. Henning SJ 1981 Postnatal development: coordination of feeding, digestion, and metabolism. Am J Physiol G199-G214

18. Henning SJ, Leeper LL 1982 Coordinate loss of glucocorticoid responsiveness by intestinal enzymes during postnatal development. Am J Physiol 242:G89G94

19. Herbst JJ, Koldovsky O 1972 Cell migration and cortisone induction of sucrase activity in jejunum and ileum. Biochem J 126:471-476

20. Smith JB and Rozengurt E 1978 Serum stimulates the $\mathrm{Na}^{+}, \mathrm{K}^{+}$pump in quiescent fibroblasts by increasing $\mathrm{Na}^{+}$entry. Proc Natl Acad Sci 75:55605564

21. Thompson SM, Sellin JH 1986 Relationships among sodium current, permeability, and $\mathrm{Na}$ activities in control and glucocorticoid-stimulated rabbit descending colon. J Membr Biol 92:121-134

22. Braun HJ, Birkenhagen JC, De Jonge HR 1984 Calcium and glucose uptake in rat small intestinal brush-border membrane vesicles. Modulation by exogenous hypercortisolism and 1,25-dihydroxy vitamin D-3. Biochim Biophys Acta 774:81-90 